surveillance definitions are widely accepted. Comparison of rehabilitation infection rates to established acute care and long-term care standards must consider selection and misclassification bias even when the same definition is being used. Comparison of infection rates between rehabilitation facilities must be based on use of the same surveillance definition. It is also clear from the data presented here that even a definition representing an authoritative consensus can introduce bias that undermines the objectives of the surveillance program. This study illustrates this principle dramatically by applying existing definitions to a new and unstudied population, but the same phenomenon undoubtedly occurs to some extent whenever surveillance is being conducted, as for example when the same definitions are applied to hospitals with different patient mixes or to different subpopulations within a hospital. It is especially important to ensure that surveillance definitions establish an operational link between the surveillance data and the prevention of infection.

\section{R E F E R E N C E S}

1. Haley RW, Gaynes RP, Aber RC, Bennett JV. Surveillance of nosocomial infections. In: Bennett JV, Brachman PS, eds. H ospital Infections. 3rd ed. Boston, MA: Little, Brown \& Co; 1992:79-108.

2. Garibaldi RA. Hospital-acquired urinary tract infections. In: Wenzel RP, ed. Prevention and Control of N osocomial Infections. 2nd ed. Baltimore, MD: Williams \& Wilkins; 1993:600-613.

3. Lewis SM, Yokoo E, Lambert R. Epidemiology of nosocomial infection in a rehabilitation hospital. Arch Phys Med Rehabil 1989;70:A-90

4. Flaherty PJ, Liljestrand JS, O'Brien TF. Infection control surveillance in a rehabilitation hospital. Arch Phys Med Rehabil 1984:65:313-315.

5. Flaherty PJ, Liljestrand JS, O'Brien TF. Urinary infections in an American rehabilitation hospital. $J$ Hosp Infect 1984;5(suppl A):75-80.

6. Yokoo E, Lewis SM, Lambert R. Prediction of urinary tract infection in rehabilitation patients. Arch Phys Med Rehabil 1989;70:A-29.

7. Waites KB, Canupp KC, DeVivo MJ. Epidemiology and risk factors for urinary tract infection following spinal cord injury. Arch Phys Med Rehabil 1993;74:691-695.

8. Lewis SM, Costa JL, Kilgore K, Siverstein B. Urinary tract infection risk in rehabilitation inpatients as a function of hospital day. Arch Phys Med Rehabil 1990;71:820.

9. Garibaldi RA. Hospital acquired urinary tract infection. In: Wenzel RP, ed. H andbook of H ospital A cquired Infections. 1st ed. Boca Raton, FL: CRC Press, Inc; 1981:513-537.

10. Garner JS, Jarvis WR, Emori TG, Horan TC, Hughes JM. CDC definitions for nosocomial infections, 1988. J Infect Control 1988;16:128-140.

11. McGeer A, Campbell B, Emori T, et al. Definitions of infection for surveillance in long-term care facilities, A m J Infect Control 1991;19:1-7.

12. Stark RP, Maki D. Bacteriuria in the catheterized patient. What quantitative level of bacteriuria is relevant. $N$ Engl J Med 1984;311:560-564.

13. Emori TG, Culver DH, Horan TC, et al. National Nosocomial Infections Surveillance System (NNIS): description of surveillance methodology. Am J Infect Control 1991;19:19-35.

14. Birnbaum D, Sheps SB. Validation of new tests. Infect Control H osp Epidemiol 1991;12:622-624.

15. Freeman J, Goldman DA, McGowan JE. Confounding and the analysis of multiple variables in hospital epidemiology. Infect Control 1978;8:465-473.

\title{
International Conference on Bloodborne Infections and Occupational Risks and Prevention to Be Held in Paris in 1995
}

\section{by Gina Pugliese, RN, MS Medical News Editor}

The conference on Bloodborne Infections: Occupational Risks and Prevention will be held June 8-9, 1995, in Paris, France. The confer- ence is being organized by the Health Service Section of the International Social Security Association. The goal is to provide an opportunity for international multidisciplinary exchanges on the risks involved, prevention strategies, equipment safety, vaccinations and prophylaxis to prevent occupationally related bloodborne infections. For additional information write to: STRATIS, Colloque AISS, 39 rue Censier, 75005 Paris, France; telephone 1-43-31-4411; FAX: 1-47-07-58-22. 